earthquake of January, 1869, the direction of the loud banging sounds like artillery was carefully marked again t a jeak in the Naga Hill range. Bearings by the prismatic compass subsequertly sent to Calcatta to Dr. H. B. Medlicott, turned out to be within $3^{\circ}$ of the trie line to Chedutra and Ramree, the active volcanic centre, 550 miles off. I cannot exactly see how the difference of the indensity assists us in directing to the sound. I find I jarige that best by facing it and remaining still, and verify the direction best by looking (with the eyes only) about $10^{\circ}$ to right, and then $10^{\circ}$ to left, which, if I do not move the head, soon enables me to fix by eye the direction pretty cloce.

Sibsagar, Asam, October 27

S. E. PEAL

\section{An Audible Photometer}

IN your issue of September 22 (vol. xxiv. p. 49I, British Association Reports) Mr. Lant Carpenter mentions an idea of his about an "audible photometer." 'The same idea occurred to me some six months ago. As my plan seems to be much more simple than Mr. Carpenter's, dispensing with intermitting beams and rotating disks, perhaps you will allow me a little space to describe it. I require only one photophonic receiver, whereas Mr. Caripenter mentions "two precisely similar receivers," which is difficult, if not wholly impossible, to obtain. $\Lambda$ is a small battery, $B$ an induction-coil with the ordinary vilbrating nagnetic interrupter, and with a high-resistance secondary coil; $\mathrm{C}$ is the Wheatstonebridge combination, $\mathrm{S} E$ a selenium cell, with its working surface

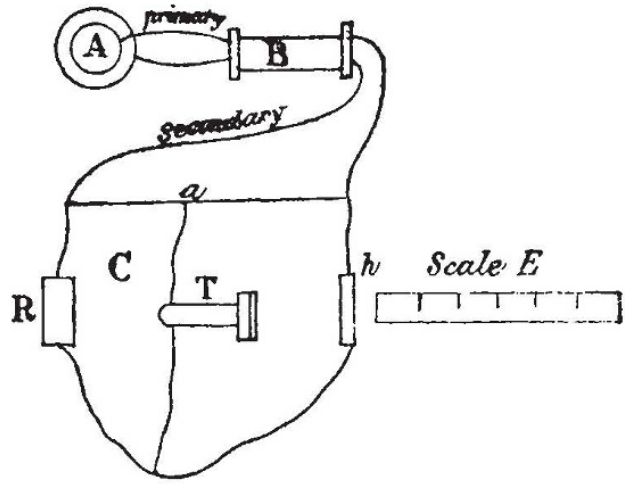

turned to the scale $E ; R$ is a high resistance of about the value of the seleninm cell ; $a$ is a sliding contact, $\mathrm{T}$ a bigh resistance telephone. Now I place ou the scale E a standard candle at a distance $d$ from selenium cell, and move the sliding contact till no sound is emitted from the telephone. Then the wirc connections are left wholly unaltered, and the candle is taken away. Now I place the light I wish to compare with the standard candle on the scale $\mathrm{F}$, and move it along the scale till the telephone is again silent. Be the distance of the light from the selenium cell now $\mathrm{n}$, then its luminous intensity is

$$
\frac{D^{2}}{d^{2}} \text { standard candles. }
$$

As, on after-thought, I greatly doubted the fitness of selenium for photometric purposes (which d ubts became the stronger the more I read about the suhject), I did not pursue my idea, which could only result in an addition to the long li-t of practically u:eless photometers. The above may perhaps be used as a college experiment for demonstrating the law of the square of distances.

Delft, November 21

J. W. GILTAY

\section{Extraordinary Atmospheric Phenomenon}

I INCLOSE a paragraph from the Glasgow Evening Citizin of this date relating to that peculiar form of lightning known as fire-balls. The explanation of the explosion in the funnel is, I think, erroneous, it having been cauced hy the explosion of the fire-lall, thus driving out the smoke by the fire-doors. The aurora was very bright here on Wednesday evening, showing Piazzi Smyth's line with a small direct vision spectroscope. Before the eye became sufficiently sensitive for measurement, clouds cut off the bright part. The aurora was a general bright northern glow without streamers, and was observed brightest a litile after eight (p.m.). These notes may be of tuse to you in connection with those of other olsservers.

Cove Castle, Loch Long, N.B., November 25

\section{Extraordinary Phenominon of the Stom}

Those on board the Campbelton Steamer Kinloch (Capt. Kerr), which left Greenock on its usual run about half-past cleven o'clock on Tuesday morning after the storm that raged during the night, had a somewhat extraordinary experience while passing down the Firth. The vessel was enveloped in a dense shower of bail, and for some time it was awfully dark, and occasionally the vessel was lit up by vivid flashes of lightning. One of the fiashes was very bright, and its shape was something like that of the arteries of the human body, with a central column all shattered and broken. A bout noun, while opposite the Cloch I ighthouse, and not far from the shore, the captain observed immer' iately over the ship what appeared to be a series of clear balls of lightning, each abont a foot in length, and resemblin, a chain, except that they were di:connected. This phenomenon was quickly succeeded by an explosion in the funnel of the steaner, and several halls of fire upon the bridge running about, and then bounding off into the water. The first impression of the spectators was that sorrething had exploded on board, but on inquiry it was found that this was nut the case. The nuate stated, bowever, that a hall of lightning had almost struck him where he stond. A firemen ru.hed upon deck to see what had happened, as the engine-rom was filled with smol:c, and a choling sensation was experienced below. The explanation appears to be that a portion of the lig! tning had pase el down the funnel until its force was spent by the fire, and the sudden recivery of the drausht of the funnel afterwards accousated fur the loud report that was heard. The captain, in his long experience at sea, never encountered such a pheno enou before, and it nay be taken as an indication of the extraordinary atmospheric forces which had been at work during the storm, and which scemed to centre in this locality.

\section{Papin}

Is the revicw of my "Lifc and Letters of Papin" 1 in NATURE, vol. xxiv. p. 378 , the hope is cxpressed that I might succeed "to fill the lacunic in the career of this remarkatJe unan." The only important blank remaining now in our knowledge of Papin's life consists in our ignorance of the time of his death. We may ret assured that he died in Iond $n$, and therefore this blank is not likely to be filled but by a per-sin who is familiar with the city and it: inhabitants of the present atd of the beginning of la-t century. Papin died about 1712. P'uring 1700 he lived at "Madam Portal chez M. Charrun, apothécaire cans Compton Strect, proche St. Anne." As it is not probable that he clian red his lodgings licfore his death a search in the registers of the district to which Compt on Street belenged (if they are in existence) would lead to results equally important for the history of science and for that of teclinology. Mlaybe a reader of this note who enjoys such opportunities will render me his assistance in this thankful task.

I avail mysclf of this opportunity of correcting a few slight mistakes " hich have found their way into the otherwise excellent r'sumé. Not P'apin but Leibnitz is the author of the letter of February 4, 1707, which contained the first jder of the "hot-air engine." I.eibnitz is therefore the inventor of the same. That beat, in which l'apin left Cas cl in 1707 to sail to Bremen, was not a "steain propeller boat," lut a small ship with padclewhecls to be worked by the sailors. It was not Papin's intention to procerd to lingland in that boat. He left Caisel with proofs of the favour and goodwill of the Iand rraf, which re. mained unchanred to the end. Lastly, hefore l'apin no steamengine existeci; he is the real inventor of the same, for he in 169 a first announced the idea, and tested it by experiments of utilising the pressure of stean as mo:ive power for engines. 'This, his first engine, had a piston inside a cylinder. Such an arrangement was not at all new at that time; other machines had the same, as, for instance, the gunpowder engine of IIuyghens, which sugges'ed the invention of Pajin. I,eilnitz. corresponded with the inventor about this engine much later, and made valuable propositions, but the correspindence of these

- Leibnizen's und Huygens' Briefwechsel mit Papin, nebst der Biographie Papin's und einigen zugetrïrigen Br eficn und Arten-tücken. Bearbeitet und auf Kosten der Kïniglichen Preussischen Akademie der Wissenschaften haratusgegeben von Dr. Ernst Ger'a 